\title{
Effectiveness Of Baby Massage On The Increase Of Baby Weight Aged 6 - 12 Months In Gayaman Village, Mojoanyar District, Mojokerto Regency
}

\author{
Titiek Idayanti*, Rina Widiyawati \\ STIKes Dian Husada Mojokerto, Indonesia \\ *ti2k.nurul@gmail.com
}

\begin{abstract}
Based on the phenomenon that occurred in Gayaman Village, Mojoanyar District, Mojokerto Regency, many children still experience delayed growth or do not gain weight every month, and the weight of some children is not in accordance with their age. This study aims to analyze the effectiveness of baby massage on the increase of baby weight aged 6-12 months in Gayaman Village, Mojoanyar District, Mojokerto Regency.

The design used was a pre-experimental type of one group pre post-test design. The research variables used included the implementation of baby massage as an independent variable and the increase in baby weight as the dependent variable. The study population was all babies aged 6-12 months who experienced underweight in the Gayaman Village totalling 28 babies. Samples were taken using a total sampling technique of 28 respondents. Data were collected by observation and subsequently tested using paired ttest.

The average change in respondents' weight before and after the baby massage is 114 grams. Paired t-test results show $\rho$ value $=0.011$ (95\% CI: -.2005 - -. 0281). $\rho$ value $=$ $0.011<\alpha=0.05$, indicating that $\mathrm{H} 0$ is rejected and $\mathrm{H} 1$ is accepted. Therefore, there is an effect of baby massage on baby growth aged 6-12 months in Gayaman Village, Mojoanyar District, Mojokerto Regency.

It is recommended for health workers to provide health education regarding the way to do the right baby massage to support in providing knowledge and expertise to parents in doing baby massage independently at home to help to reach the optimal growth process, especially the baby's weight gain. It is expected that baby massage will be used as a program for newborn care so that baby growth and development can run optimally.
\end{abstract}

Keywords : Increase in body weight, Baby massage, Babies aged 6-12 months

Received June 15, 2020; Revised July 8, 2020; Accepted August 14, 2020 


\section{STRADA Jurnal Ilmiah Kesehatan}

DOI: $10.30994 /$ sjik.v9i2.359

ISSN: 2252-3847 (print); 2614-350X (online)

Vol.9 No.2 November 2020 Page.708-715

\section{BACKGROUND}

The baby period is a stage where growth is very fast, starting from the baby is born to one year old. It is considered a critical period in growth since it is a period of the basics of the beginning of his or her life. The baby is considered to be the golden age or the golden period since at this time, the body growth occurs. Some factors affecting the growth process of babies include heredity and the environment. This genetic factor is linked to genes given from a father and mother to the child. Environmental factors involve the biological, physical, and psychological environment. Based on the phenomenon that occurred in Gayaman Village, Mojoanyar District, Mojokerto Regency, many children still experience delayed growth, where there is no weight gain watch month when attending the Family Planning Service Post (Posyandu).

According to WHO (2015), the prevalence of babies whose weights are not in line with their age becomes a public health problem if the prevalence is $20 \%$ or more. Therefore, the percentage of babies whose weight does not conform to the age in Indonesia remains high and is a health problem that must be addressed. Compared to some neighboring countries, the prevalence of underweight babies in Indonesia was also the highest compared to Myanmar (35\%), Vietnam (23\%), Malaysia (17\%), Thailand (16\%), and Singapore (4\%). The Global Nutrition Report of 2014 showed that Indonesia was listed in 17 countries, among 117 countries, that had three nutritional problems, including stunting, wasting, and overweight in toddlers. Based on the Ministry of Health (2016), the percentage of nutritional status of underweight babies (not based on their age) in Indonesia in 2013 was 37.2\%, compared to 2010 (35.6\%), and 2007 (36.8\%), which did not indicate significant decrease/improvement. The highest percentages in 2013 were in the provinces of East Nusa Tenggara (51.7\%), West Sulawesi (48.0\%), and West Nusa Tenggara $(45.3 \%)$. Meanwhile, the lowest percentages were in the provinces of Riau Islands (26.3\%), DI Yogyakarta (27.2\%), and DKI Jakarta (27.5\%). In 2014, $29 \%$ of Indonesian toddlers were included in the underweight category, with the highest percentage also in the provinces of East Nusa Tenggara and West Sulawesi. An examination of Early Childhood Development (DDTK) of toddlers and preschoolers in East Java in 2010 was performed on $63.48 \%$ of toddlers. This coverage reduced compared to 2009 which was $64.03 \%$ of toddlers. It is due to low maternal education and lack of parenting skills in providing stimulation and good nutrition required by the baby. Based on the results of a previous study conducted by researchers in Gayaman Village, there were 28 infants aged 6-12 months who experienced underweight (body weight was not in accordance with the age of the baby).

Growth is a continuous process that is constant and is part of the development process (Uwong, 2009). An increase and decrease in body weight must be taken into account during infancy, including adjustment in height, weight, teeth, bone structure, and sexual characteristics (Mansur, 2009). Parents or families take a significant role not only to provide adequate nutrition, give attention and affection, but also to provide stimulus to support the process of neural networks so that it influences the growth process in infants (Wijayanti, 2006). At the beginning of growth, parents take a role in providing tactile stimuli so that coordination of the baby's reflexes and movements are formed properly. One way to increase the infants' growth that can be performed safely, comfortably, practically, and affordably is by applying the baby massage. Baby massage is an effective way to increase delayed growth by providing stimuli to the baby through body massage. The baby who is provided with stimuli will experience growth well and fast. This growth is quantitative. Impacts occurred if no action is taken will lead to delayed growth. The 


\section{STRADA Jurnal Ilmiah Kesehatan}

DOI: $10.30994 /$ sjik.v9i2.359

ISSN: 2252-3847 (print); 2614-350X (online)

Vol.9 No.2 November 2020 Page.708-715

baby's body weight doubles the birth weight at the end of the first 6 months. Meanwhile, at the age of 6-12 months, weight gain each week ranges from 85-400 grams. Bodyweight will increase three times the birth weight at the end of the first year (Wong, Hockenberry, Wilson, Perry, \& Lowdermilk, 2003; Hidayat, 2008).

Taking into account that parents hold an essential role in the growth and development of children, they should improve their knowledge in facilitating children's needs, one of which is by understanding the stimulation that can be given to their child. Therefore, baby massages performed by parents can stimulate children's development according to their age. Besides, information can be understood and can affect behavior change in society, particularly for mothers by using counseling as one of the methods for conveying information.

\section{METHODS}

The type of research used was pre-experimental with a type of one group pre-posttests design. The research population was all babies aged 6-12 months in Gayaman Village, Mojoanyar District, Mojokerto Regency with a total of 28 infants. The sample collection was performed using a total sampling technique, which is 28 existing babies. Analysis of the data obtained is subsequently processed by using a statistical test of the Paired T-Test on a statistical program for windows or SPSS.

\section{RESULTS}

1. General Data

a. Characteristics of Respondents Based on Age

Table 1 Characteristics of Respondents Based on Age in Gayaman Village Mojoanyar District

\begin{tabular}{|l|l|l|l|l|}
\hline Variable & Mean & SD & Min & Max \\
\hline Mother's age & 32.39 & 4.283 & 25 & 38 \\
\hline
\end{tabular}

Source: Primary Data

Table 1 shows that the mean value of maternal age is 32.39 (95\% CI: 30.09-34.50); the standard deviation is 4.283 ; the youngest age is 25 years, while the oldest age is 38 years.

b. Characteristics of Respondents Based on Employment

Table 2 Characteristics of Respondents Based on Mother's Occupation in Gayaman Village, Mojoanyar District

\begin{tabular}{|l|l|l|l|}
\hline $\begin{array}{l}\text { No } \\
.\end{array}$ & Mother's Occupation & Frequency (f) & Percentage (\%) \\
\hline 1 & Private Sector Worker & 7 & 25 \\
\hline 2 & Entrepreneur & 6 & 21.5 \\
\hline 3 & Government Employees & 2 & 7,1 \\
\hline 4 & Unemployed/ Housewife & 13 & 46.4 \\
\hline & Total & 28 & 100 \\
\hline
\end{tabular}

Source: Primary Data

Table 2 shows that almost half of the respondents are not working or being housewives of 13 respondents $(46.4 \%)$ 


\section{STRADA Jurnal Ilmiah Kesehatan}

DOI: $10.30994 /$ sjik.v9i2.359

ISSN: 2252-3847 (print); 2614-350X (online)

Vol.9 No.2 November 2020 Page.708-715

c. Characteristics of Respondents Based on Education

Table 3 Characteristics of Respondents Based on education in Gayaman Village, Mojoanyar District

\begin{tabular}{|l|l|l|l|}
\hline $\begin{array}{l}\text { No } \\
\cdot\end{array}$ & Education & Frequency (f) & Percentage (\%) \\
\hline 1 & Elementary School & 0 & 0 \\
\hline 2 & Junior High School & 7 & 25 \\
\hline 3 & Senior High School & 17 & 60.7 \\
\hline 4 & University & 4 & 14.3 \\
\hline \multicolumn{2}{|l|}{ Total } & 28 & 100 \\
\hline
\end{tabular}

Source: Primary Data

Table 3 shows that the majority of respondents have a high school education of 17 respondents $(60.7 \%)$.

d. Characteristics of Respondents by Gender

Table 4 Characteristics of Respondents by Gender in Gayaman Village, Mojoanyar District

\begin{tabular}{|l|l|l|l|}
\hline $\begin{array}{l}\text { No } \\
.\end{array}$ & $\begin{array}{l}\text { Baby's } \\
\text { Gender }\end{array}$ & $\begin{array}{l}\text { Frequency } \\
\text { (f) }\end{array}$ & $\begin{array}{l}\text { Percentag } \\
\text { e (\%) }\end{array}$ \\
\hline 1 & Male & 10 & 35.7 \\
\hline 2 & Female & 18 & 64.3 \\
\hline \multicolumn{2}{|l|}{ Total } & 28 & 100 \\
\hline
\end{tabular}

Source: Primary Data

Table 4 shows that the majority of the gender of the baby is a female of 18 respondents $(64.3 \%)$.

2. Specific Data

1. Characteristics based on Weight Before Baby Massage

Table 5 Characteristics of Respondents by Weight (in grams) Before a baby massage is performed in Gayaman Village, Mojoanyar District

\begin{tabular}{|l|l|l|l|l|}
\hline Variable & Mean & SD & Min & Max \\
\hline $\begin{array}{l}\text { BW } \\
\text { Before }\end{array}$ & 6.557 & .8158 & 5.0 & 7.8 \\
\hline
\end{tabular}

Notes: BW in grams

Table 5 shows that the average value of body weight before the massage is 6.557 . The standard deviation is 0.8158 . The lowest weight is $5000 \mathrm{gr}$ and the highest weight is 7800 gr.

2. Frequency Distribution of Respondents by Weight After Baby Massage

Table 6 Frequency Distribution of Respondents by Weight (in grams) After Baby Massage in Gayaman Village, Mojoanyar District

\begin{tabular}{|l|l|l|l|l|}
\hline Variable & Mean & SD & Min & Max \\
\hline BW & 6.671 & .79 & 5.2 & 8.0 \\
\hline
\end{tabular}




\section{STRADA Jurnal Ilmiah Kesehatan}

DOI: $10.30994 /$ sjik.v9i2.359

ISSN: 2252-3847 (print); 2614-350X (online)

Vol.9 No.2 November 2020 Page.708-715

\begin{tabular}{|l|l|l|l|l|}
\hline after & & 99 & & \\
\hline
\end{tabular}

Notes: $B W$ in grams

Table 6 shows that the average value of body weight after the massage is 6,671 . The standard deviation is .7999 . The lowest weight is 5200 grams and the highest weight is 8000 grams.

3. The difference in body weight in Pre-test and Post-test

Table 7 Frequency Distribution of Respondents by Weight (in grams) Before and After Baby Massage in Gayaman Village, Mojoanyar District

Paired Samples Test

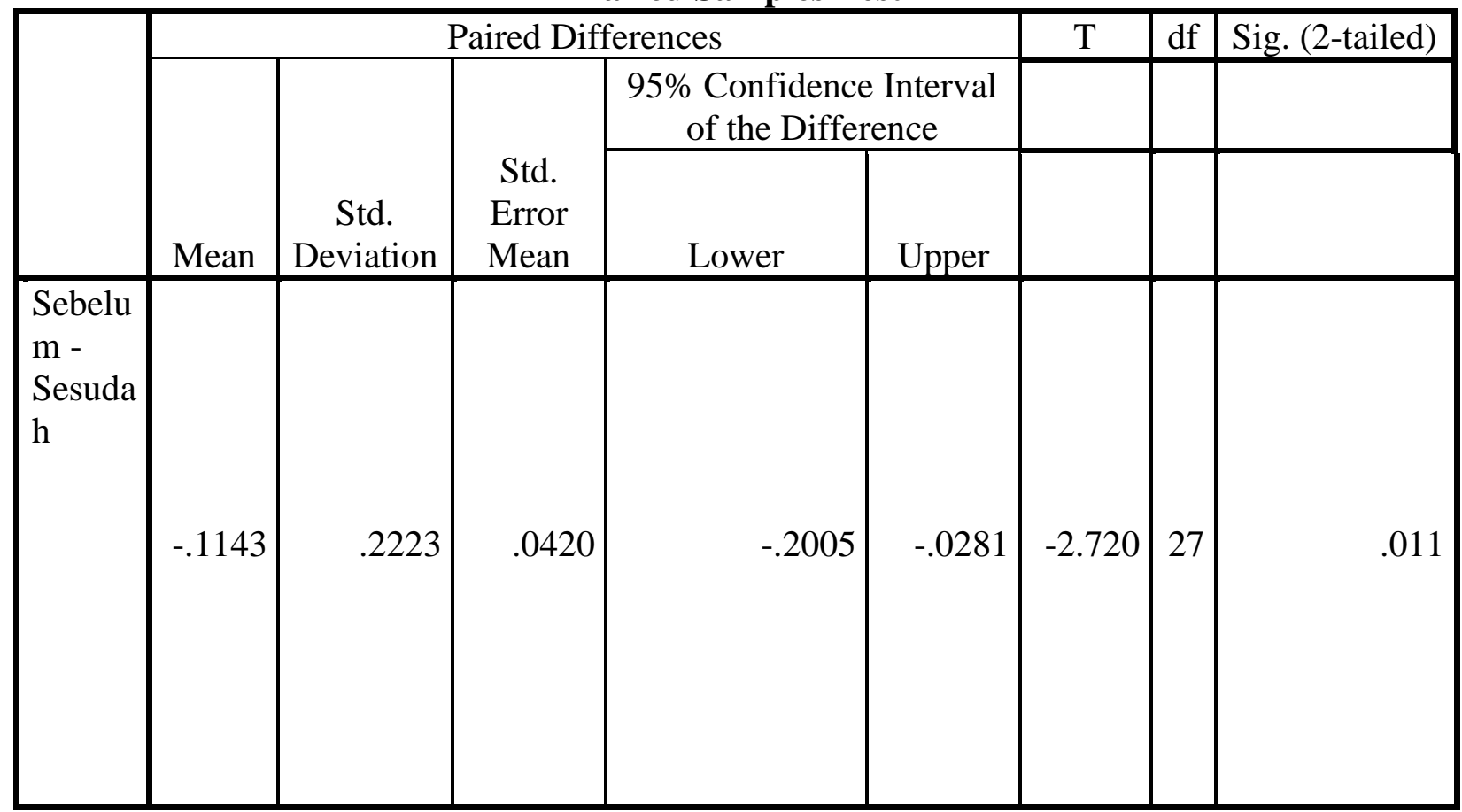

Notes: $B W$ in grams

Table 7 of the results of the paired t-test is interpreted that the average change in respondent's weight before and after the massage is -.1143 based on the $\rho$ value $=0.011 \alpha$ $=0.05$ so that the $\rho$ value $<\alpha$, indicating that $\mathrm{H}_{0}$ is rejected and $\mathrm{H}_{1}$ is accepted. Therefore, there is an effect of baby massage on the increase of baby weight aged 6-12 months in Gayaman Village, Mojoanyar District.

\section{DISCUSSION}

\section{Baby Weight Before Baby Massage}

Table 5 shows that the average value of body weight before the massage is 6.557 , the standard deviation is .8158 , the lowest weight is $5000 \mathrm{gr}$ and the highest weight is 7800 gr. Based on the estimation results, it can be concluded that the average baby weight is between 5000 - 7800 gram.

According to Yuriastien (2009), growth is a gradual increase in body organs and tissues. It can be observed from the children's weight gain and height. The growth process is more often examined at regular anthropometric examinations. Normal babies follow a steady growth curve. A deviation of the normal curve direction is an indicator of 


\section{STRADA Jurnal Ilmiah Kesehatan}

DOI: $10.30994 /$ sjik.v9i2.359

ISSN: 2252-3847 (print); 2614-350X (online)

Vol.9 No.2 November 2020 Page.708-715

abnormalities caused by illness/hormones/malnutrition (Hassan, 2012). According to the researchers, the results of this study indicate that the respondents' weight is normal or in accordance with their age. Preliminary studies conducted by the researchers show that 28 babies ahe 6-12 months are underweight or the weight does not match the age.

\section{Baby Weight After Baby Massage}

Table 6 shows that the average value of body weight after the baby massage is 6.671, the standard deviation is .7999, the lowest weight is $5200 \mathrm{gr}$ and the highest weight is 8000 gr. Based on the estimation results, it can be concluded that the average baby weight is between $5200-8000$ gram.

Roesli (2008) stated that one of the benefits of baby massage is to increase baby weight and give positive biochemical and physical effects. Baby massage causes an increase in vagus nerve activity and stimulates digestive hormones including insulin and gastrin. Insulin plays a role in metabolism, increases carbohydrate metabolism, glycogen storage, synthesis of fatty acids, uptake of amino acid protein synthesis. Therefore, insulin is an essential anabolic hormone that works on various tissues including liver, fat, and muscle. Increased insulin and gastrin can stimulate digestive function to better-absorbed food juices. Better absorption of food will cause the baby to starve quickly and therefore they are more likely to breastfeed.

According to the researchers, the results of this study show that there is an increase in baby weight after massage in infants. When the baby is calm and after bathing in the morning or evening, massage is done for 15 times for each movement so that the massage can affect the metabolic processes in the baby's body. Therefore, a good and smooth metabolic process affects the absorption of nutrients and nourishment maximally.

\section{The difference in Weight Before and After Baby Massage}

Table 7 of the results of the paired t-test is interpreted that the average change in respondents' weight before and after the massage is .1143. Based on the $\rho$ value $=0.011 \alpha$ $=0.05$, the $\rho$ value $<\alpha$, indicating that $\mathrm{H}_{0}$ is rejected while $\mathrm{H}_{1}$ accepted. Therefore, baby massage affects increase baby weight aged 6-12 months in Gayaman Village, Mojoanyar District - Mojokerto.

The results of this study are in accordance with a study conducted by Triana (2012) that after a statistical test using the paired sample t-test, a t value of -14.563 was obtained, indicating that there was a difference between the baby's body weight before and after baby massage and a value of Asymp. Sig. (2-tailed) of 0,000 which had a smaller value than the research $\alpha$ of 0.05 indicates that $\mathrm{H}_{\mathrm{o}}$ is rejected and $\mathrm{H}_{\mathrm{a}}$ is accepted. Further, it can be seen that there is a significant difference between changes in baby weight before and after being provided with baby massage. This is because all respondents receive baby massage treatment.

According to Roesli (2008), the benefits of baby massage is a positive biochemical effect of reducing levels of stress hormones (catecholamine), increasing levels of the immune system (immunoglobulin), particularly $\operatorname{IgG}, \operatorname{IgA}$ and $\operatorname{IgM}$, and increasing serotonin levels. Positive clinical effects are changing brain waves positively, improving blood circulation and breathing, stimulating digestive and disposal functions, increasing weight gain, reducing depression and tension, making sleep soundly, reducing pain, reducing bloating and abdominal pain, increasing parent and baby relationships and increasing the volume of breast milk. 


\section{STRADA Jurnal Ilmiah Kesehatan}

DOI: $10.30994 /$ sjik.v9i2.359

ISSN: 2252-3847 (print); 2614-350X (online)

Vol.9 No.2 November 2020 Page.708-715

The results of the analysis show that the maximum benefits of massage can be obtained by considering the right massage time and frequency of the massage for each massage movement. The most appropriate massage time is in the morning before having a bath because of the practical reason that the rest of the massage oil can be easier to clean. Massaging can be performed when the baby is relaxed and calm. The massage is performed regularly on the baby's legs, abdomen, chest, hands, back. Each stretching movement is repeated or done 15 times, which can increase baby weight. During the massage, the potential for nerve action occurs to stimulate the vagus nerve and subsequently stimulates an increase in intestinal peristalsis, so that the absorption of food in the body will be more optimal. Baby massage can also improve blood circulation and increase cell metabolism, so that baby weight will increase.

\section{CONCLUSIONS}

There is an effect of baby massage on the increase of baby massage aged 6-12 months in Gayaman Village, Mojoanyar District - Mojokerto as evidenced by the $\rho$ value $=0.011 \alpha=0.05$ so that the $\rho$ value $<\alpha$. It shows that the baby massage can affect the baby growth aged 6-12 months, which is the increase in infant weight.

\section{REFERENCES}

Andrews. J, (2008), Elite Massage Therapy, Madison Ave, San Diego.

Arikunto, S. (2010). Prosedur Penelitian: Suatu Pendekatan Praktik. Jakarta: Rineka Cipta.

Aurelia. (2011). Tips Pemijatan Pada Bayi. Yogyakarta: Trimedia

Dewi, N.N. Dkk (2010). Effect of massage stimulation on weight gain in full-term infants. Paediatrica Indonesiana, 51, 202-206.

Dewi, Siska. (2013). Pijat dan Asupan Gizi Tepat. Yogyakarta: Pustaka Baru Press

Hidayat. (2007). Metode Penelitian Kebidanan dan Teknik Analisis Data, Jakarta: Penerbit Salemba Medika.

Hidayat. (2009). Ilmu Pengantar Keperawatan Anak. Jakarta: Salemba Medika

Kristiyanasari, Weni. (2010). ASI, Menyusui \&Sadari. Yogyakarta: Nuha Medika. Yogyakarta

Mubarak, Wahit Iqbal, et al. (2007). Ilmu Keperawatan Komunitas Konsep Dan Aplikasi. Jakarta: Salemba Medika

Notoatmodjo, Soekidjo. (2010). Metodologi Penelitian Kesehatan, Jakarta: Rineka Cipta.

Notoatmodjo, S. (2010). Ilmu Perilaku Kesehatan. Jakarta: PT Rineka Cipta

Novitasari. (2012). Teori Pijat Bayi - Tingkat pengetahuan ibu tentang pijat bayi di dukuh cemetuk desa lorogtawangsari sukoharjo Tahun 2012.

Nursalam. (2013). Konsep dan Penerapan Metodologi Penelitian Ilmu Keperawatan. Jakarta: Salemba Medika

Potter, P. A., \& Perry, A. G. (2005). Fundamental keperawatan. (ed. 7). Jakarta: Salemba Medika.

Rahmawati.

(2012). Perkembangan

anak.

Available

on http://www.rahamwati.wordpres.com accessed on January 15, 2016

Roesli, Utami. (2008). Pedoman Pijat Bayi. Jakarta: Trubus Agriwidya

Santi Enidya. (2012). Buku Pintar Pijat Bayi Untuk Tumbuh Kembang Optimal Sehat \& Cerdas. Yogyakarta: Pinang Mera

Saryono. (2010). Metodologi Penelitian Kebidanan. Yogyakarta: Nuha Medika 


\section{STRADA Jurnal Ilmiah Kesehatan}

DOI: $10.30994 /$ sjik.v9i2.359

ISSN: 2252-3847 (print); 2614-350X (online)

Vol.9 No.2 November 2020 Page.708-715

Suhartini. (2013). Tahap Perkembangan Motorik Bayi. Jurusan Pendidikan Kesehatan Rekreasi FKIK Universits Negeri Yogyakarta.

Supartini. (2004). Buku ajar konsep dasar keperawatan anak. Jakarta. EGC.

Suryana. (2007). Tahap-Tahapan Penelitian Kualitatif. Teaching Module for the Faculty of Administration of the Indonesian University of Education.

Widodo Agus. (2008). Efektifitas massage efflurage terhadap perkembangan Jurnal Kesehatan ISSN 1979-7621, Vol.1, No.1, June 2008 pp. 67-72.

Wong, D. L. (2009). Pedoman klinis keperawatan pediatrik. (ed. 4). (Monica Ester \& Sari Kurnianingsih, Translators.). Jakarta: EGC.

Yuriastien Effiana, et al. (2009). Games therapy untuk Kecerdasan Bayi dan Balita, Jakarta: WahyuMedia.

Yusuf LN. (2006). Psikologi Perkembangan Anak dan Ramaja. Jakarta: PT. Rineka Cipta. 